\title{
Studi Awal Desain Pebble Bed Reactor Berbasis HTR-PM Dengan Resirkulasi Bahan Bakar Once-Through-Then-Out
}

\author{
Topan Setiadipura*, Jupiter S. Pane, Zuhair \\ Pusat Teknologi dan Keselamatan Reaktor Nuklir -BATAN \\ Gedung 80, Puspiptek, Serpong, Tangsel, BANTEN, 15310, Indonesia
}

\begin{tabular}{l}
\hline INFORMASI ARTIKEL \\
\hline Riwayat Artikel: \\
Diterima: \\
22 Juni 2016 \\
Diterima dalam bentuk revisi: \\
30 Juli 2016 \\
Disetujui: \\
10 Agustus 2016 \\
\end{tabular}

Kata kunci:

Pebble bed reactor

Once-through-then-out

HTR-PM

\begin{abstract}
ABSTRAK
STUDI AWAL DESAIN PEBBLE BED REACTOR BERBASIS HTR-PM DENGAN RESIRKULASI BAHAN BAKAR ONCE-THROUGH-THEN-OUT. Reaktor nuklir tipe pebble bed reactor (PBR) adalah salah satu reaktor canggih dengan fitur keselamatan pasif yang kuat. Pada desain tipe ini berpotensi untuk dilakukan kogenerasi yang bermanfaat untuk pengolahan berbagai mineral di berbagai pulau di Indonesia. Operasi PBR dapat lebih disederhanakan dengan menerapkan skema pengisian bahan bakar once-through-then-out (OTTO) dimana bahan bakar pebble hanya akan melewati teras reaktor sekali. Penelitian ini bertujuan untuk mengetahui dampak kuantitatif dari perubahan skema resirkulasi bahan bakar terhadap performa teras PBR dan mendapatkan desain optimasi awal reaktor tipe PBR dengan skema resirkulasi OTTO. Perangkat lunak PEBBED digunakan untuk memperoleh teras setimbang PBR dengan berbagai skema resirkulasi bahan bakar. Hasil perhitungan memberikan data dampak penerapan skema resirkulasi bahan bakar berbeda, khususnya skema OTTO. Selanjutnya diperoleh desain optimasi awal desain PBR berbasis HTR-PM dengan skema siklus OTTO dimana daya harus diturunkan hingga $115 \mathrm{MWt}$ untuk mempertahankan fitur keselamatan. Kesederhanaan operasi reaktor dan komponen yang lebih sedikit dengan skema OTTO tetap membuat desain optimasi awal ini menjadi alternatif desain yang menarik, meskipun daya yang diperoleh lebih kecil dari desain referensi.
\end{abstract}

\begin{abstract}
PRELIMINARY DESIGN STUDY OF PEBBLE BED REACTOR HTR-PM BASE USING ONCE-THROUGH-THEN-OUT FUEL RECIRCULATION. Pebble Bed Reactor (PBR) is one of the advanced reactor type implementing strong passive safety feature. In this type of design has the potential to do a cogeneration useful for the treatment of various minerals in various islands in Indonesia. The operation of the PBR can be simplified by implementing once-through-then-out (OTTO) fuel recirculation scheme in which pebble fuel only pass the core once time. The purpose of this research is to understand quantitative influence of the changing of fuel element recirculation on the PBR core performance and to find preliminary optimization design of PBR type reactor with OTTO recirculation scheme. PEBBED software was used to find PBR equilibrium core. The calculation result gives quantitative data on the impact of implementing a different fuel recirculation, especially using OTTO scheme. Furthermore, an early optimized PBR design based on HTR-PM using OTTO scheme was obtained where the power must be downgraded into $115 \mathrm{MWt}$ in order to preserve the safety feature. The simplicity of the reactor operation and the reduction of reactor component with OTTO scheme still make this early optimized design an interesting alternative design, despite its power reduction from the reference design.

Keywords: pebble bed reactor, once-through-then-out, HTR-PM
\end{abstract}

\section{PENDAHULUAN}

Reaktor nuklir tipe pebble bed reactor (PBR) adalah salah satu reaktor canggih dengan fitur keselamatan pasif yang kuat. Berbagai desain reaktor tipe ini sedang dikembangkan di beberapa negera dengan target untuk bisa segera melakukan

${ }^{*}$ Penulis korespondensi.

E-mail: tsdipura@batan.go.id komersialisasi, misalnya StarCore di Kanada, Xe-100 di Amerika, dan HTR-PM di Tiongkok[1]. Desain HTR-PM merupakan kelanjutan dari program HTR-10 yang telah sukses dilakukan sebelumnya, dan sekarang merupakan desain PBR yang paling dekat menuju komersialisasi[2]. Dengan konsep modular, desain PBR dapat secara fleksibel memenuhi kebutuhan listrik dengan spektrum yang lebih luas. Bagi Indonesia dengan 
kebutuhan listrik yang tersebar di berbagai pulau dengan kapasitas infrastruktur yang terbatas, konsep PBR modular sangatlah tepat. Terlebih potensi kogenerasi dari desain PBR yang bisa bermanfaat untuk pengolahan berbagai mineral di berbagai pulau di Indonesia[3]. Untuk dapat digunakan secara masif dan di daerah terpencil, salah satu faktor yang penting dari desain reaktor yang akan diterapkan adalah kesederhanaan dalam pengoperasian reaktor tersebut. Untuk tipe PBR, pengoperasian dapat lebih disederhanakan lagi dengan menerapkan skema pengisian bahan bakar once-throughthen-out (OTTO) dimana bahan bakar pebble hanya akan melewati teras reaktor sekali. Konsep resirkulasi OTTO sejak awal memang hadir untuk memberikan sistem reaktor nuklir yang lebih sederhana, diantaranya dengan menghilangkan perangkat untuk pengukuran fraksi bakar juga untuk resirkulasi bahan bakar kembali ke teras[4,5]. Konsep PBR dengan skema OTTO ini berbeda dengan skema pengisian bahan bakar yang umumnya diterapkan pada desain PBR saat ini, termasuk HTR-PM yang menerapkan skema resirkulasi bahan bakar multi-pass dimana bahan bakar pebble akan diresirkulasi kembali ke dalam teras hingga 15 kali. Kendala dalam menerapkan skema OTTO adalah adanya puncak rapat daya pada bagian atas teras yang dapat menyebabkan batas-batas keselamatan tidak dapat terpenuhi[5,6]. Sebelumnya telah dilakukan penelitian untuk melihat dampak dari berbagai skema pengisian bahan bakar dengan membagi teras kedalam beberapa zona fraksi bakar secara radial[7]. Pembagian teras ke dalam berbagai zona fraksi bakar radial pada dasarnya justru menambah kompleksitas operasi PBR sehingga tidak diaplikasikan pada desain HTR-PM terkini. Penelitian kali ini tetap pada konsep mapan dengan zona fraksi bakar tunggal dan fokus pada perubahan skema sirkulasi bahan bakar. Penelitian ini bertujuan untuk memahami secara kuantitatif dampak dari perubahan skema resirkulasi bahan bakar terhadap performa teras PBR dan mendapatkan desain optimasi awal reaktor tipe PBR dengan skema resirkulasi OTTO. Desain referensi yang digunakan dalam studi ini adalah desain HTR-PM. Penurunan daya untuk dapat memenuhi batas keselamatan dengan skema OTTO memang menjadi titik lemah, namun penerapan skema OTTO dengan operasi yang lebih sederhana dan berpotensi mengurangi biaya pembangunan diharapkan dapat menjadi alternatif desain yang menarik. Parameter desain pertama yang digunakan dalam studi ini adalah nilai maksimum pembangkitan daya per bahan bakar bola yang tidak boleh lebih dari 4.5kW[3]. Kedua, temperatur bahan bakar bola yang tidak boleh melebihi $1600^{\circ} \mathrm{C}$ ketika terjadi kecelakaan. Dalam studi ini dipilih kecelakaan Depressurized Loss-of-forced-cooling (DLOFC) yang merupakan salah satu kecelakaan terparah yang mungkin terjadi pada reaktor tipe PBR. Analisis terhadap parameter desain lainnya juga diberikan dalam studi ini. Untuk memperoleh desain PBR dengan siklus OTTO yang memenuhi kriteria desain ini dilakukan penyesuaian dengan merubah daya reaktor. Hasil penelitian ini diharapkan menjadi dasar bagi studi desain lanjutan untuk memperoleh desain PBR dengan fitur keselamatan sangat baik serta sistem pengoperasian yang lebih sederhana.

\section{METODOLOGI}

\subsection{Desain Teras dan Penanganan Bahan Bakar Pebble Bed Reactor}

Skema teras PBR ditunjukkan pada Gambar 1. Teras reaktor dilingkupi oleh reflektor grafit yang sekaligus menjadi struktur penopang teras. Diantara reflektor grafit terdapat kanal batang kendali dimana terdapat batang kendali yang dapat bergerak vertikal sesuai dengan kebutuhan operasi. Secara umum, teras PBR dapat dikendalikan dengan posisi batang kendali dari luar teras selama diameter teras aktif tidak lebih dari 3 $\mathrm{m}$. Terdapat kanal helium dingin tempat mengalirnya helium dingin dari unit pembangkit uap menuju bagian atas teras. Kemudian helium akan mengalir kebawah pada teras reaktor untuk mendinginkan dan mengambil panas dari teras. Helium panas, yang telah melewati teras, mengalir menuju unit pembangkit uap melalui koaksial hot gas duct. Bahan bakar pebble berbentuk bola dengan diameter $6 \mathrm{~cm}$ terletak pada teras reaktor secara acak dan bergerak aksial 


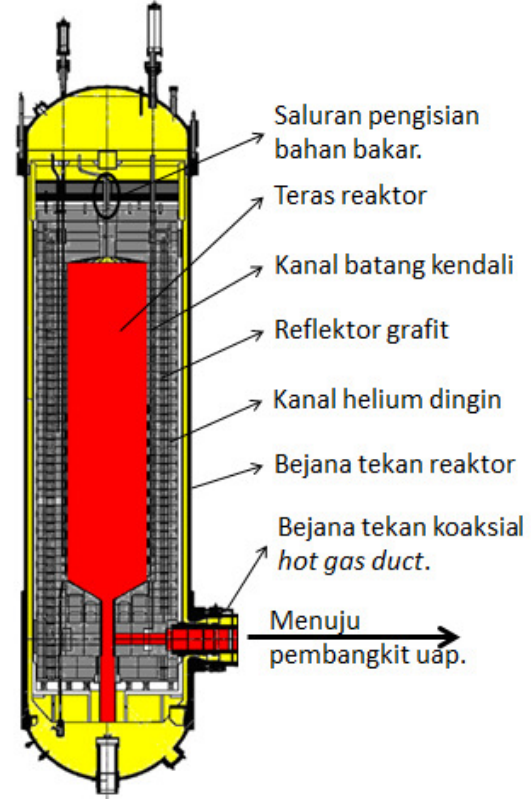

Gambar 1. Skema Tampang Lintang Teras HTR-PM[2].

selama operasi hingga keluar dari bagian bawah teras. Dari sisi operasi, skema bahan bakar ini memungkinkan pengisian bahan bakar meskipun reaktor sedang beroperasi. Secara neutronik, kemampuan ini membuat reaktivitas teras dapat dipertahankan secara stabil[8].

Penanganan bahan bakar pebble pada reaktor PBR ditunjukkan pada Gambar 2. Dari penyimpanan bahan bakar segar, bahan bakar dimasukkan ke teras oleh unit distributor sesuai dengan desain laju pengisian bahan bakar. Pada teras reaktor PBR, bahan bakar bergerak turun secara aksial hingga akhirnya keluar dari bagian bawah teras. Setelah melewati unit singulator, satu per satu bahan bakar pebble akan mengalami cek kerusakan geometri. Apabila terjadi kerusakan geometri maka bahan bakar akan dilanjutkan ke penyimpanan bahan bakar rusak. Bahan bakar yang masih utuh kemudian mengalami cek level fraksi bakar. Sedangkan untuk reaktor PBR yang menerapkan resirkulasi berulang (multi-pass) maka akan bergantung pada hasil pengukuran level fraksi bakar. Bahan bakar pebble yang telah melewati batas tertentu akan disimpan di penyimpanan bahan bakar bekas, sedangkan bahan bakar pebble yang belum memenuhi target fraksi bakarnya akan dikembalikan ke teras reaktor. Transportasi bahan bakar dilakukan dengan memanfaatkan fitur bahan bakar pebble berbentuk bola yang mudah mengalir dengan tarikan gaya gravitasi,

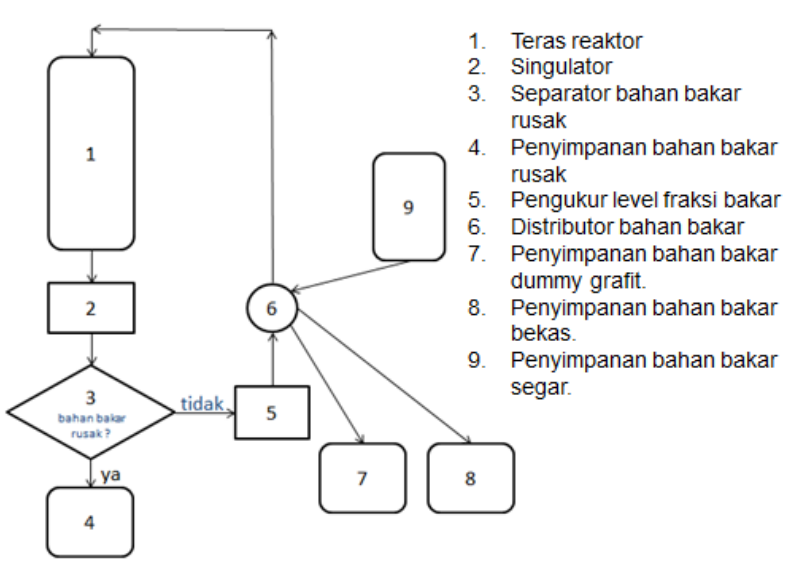

Gambar 2. Skema Penanganan Bahan Bakar Pada Reaktor Tipe Pebble Bed Reactor.

selain itu juga memanfaatkan teknologi pneumatik gas untuk melakukan transportasi pebble dari bagian yang lebih tinggi[7]. Untuk reaktor PBR yang menerapkan skema resirkulasi OTTO, maka semua bahan bakar yang keluar dari teras akan disimpan pada penyimpanan bahan bakar bekas. Skema OTTO ini dapat menambah kesederhanaan operasi reaktor PBR dengan menghilangkan unit pengukuran fraksi bakar serta perangkat untuk resirkulasi bahan bakar kembali ke teras.

\subsection{Metoda Analisis}

Perhitungan teras setimbang dilakukan dengan perangkat lunak PEBBED[9], sementara perhitungan spektrum dilakukan dengan perangkat lunak COMBINE7[10] menggunakan data nuklir ENDF/B-VII.O. Spektrum energi neutron dibagi ke dalam 8 grup, masing-masing 4 grup untuk neutron cepat dan termal. PEBBED telah validasi melalui komparasi dengan perangkat lunak VSOP serta digunakan secara intensif untuk desain PBR termasuk untuk aplikasi deepburn menggunakan bahan bakar dari TransUranium (TRU)[11,12]. PEBBED secara simultan memecahkan persamaan difusi dan persamaan deplesi bahan bakar dengan memperhatikan pergerakan bahan bakar secara aksial selama operasi reaktor. Persamaan deplesi bahan bakar yang dipecahkan ditunjukkan pada persamaan (1)[9]. Dimana, berbeda dengan persamaan deplesi untuk reaktor dengan bahan bakar statis, terdapat suku yang memasukkan faktor perubahan posisi aksial. Untuk memperoleh 
solusi teras setimbang PEBBED secara otomatis memecahkan persamaan dimana tidak terjadi lagi perubahan sebagai fungsi waktu.

$$
\begin{aligned}
\frac{\partial N_{k}(r, z, t)}{\partial t}+\frac{\partial N_{k}(r, z, t)}{\partial z} v_{z}(\mathrm{r}, \mathrm{z}) \\
=\emptyset(r, z, t) \sum_{\substack{i=l \\
q}}^{m} N_{i}(r, z, t) \sigma_{f i} y_{i k} \\
+\emptyset(r, z, t) \sum_{s=r} N_{s}(r, z, t) \sigma_{a s} y_{s k} \\
+\sum_{i=l}^{m} N_{i}(r, z, t) \lambda_{j} \alpha_{j k}-\lambda_{k} N_{k}(r, z, t) \\
-\emptyset(\vec{r}, t) N_{k}(r, z, t) \sigma_{a k}
\end{aligned}
$$

Dimana $N_{k}(r, z, t)$ adalah Densitas nuklida dari isotop $k$ pada koordinat $(r, Z)$ pada waktu $t ; v_{z}$ adalah kecepatan gerak bahan bakar; $\emptyset(r, z, t)$ adalah fluks neutron pada koordinat $(r, Z)$ pada waktu $t ; \sigma_{f i}$ adalah penampang lintang reaksi fisi isotop $i ; y_{i k}$ adalah probabilitas lahirnya isotop $k$ dari reaksi fisi isotop $i ; \sigma_{a s}$ adalah penampang lintang reaksi absorpsi isotop $s$; $y_{s k}$ adalah probabilitas lahirnya isotop $k$ dari reaksi absorpsi isotop $s ; \lambda_{j}$ adalah penampang lintang peluruhan isotop $j ;$ dan $\alpha_{j k}$ adalah probabilitas isotop $j$ meluruh menjadi isotop $k$.

Analisis panas dilakukan dengan modul termal hidraulik yang terdapat pada software PEBBED. Modul termal hidraulik ini menggunakan model analisis panas radial $1-D$ transien. Modul ini mampu menghitung transien temperatur bahan bakar dengan sumber panas awal yang diberikan. Model ini secara khusus digunakan untuk melakukan analisis terhadap temperatur bahan bakar setelah kecelakaan D-LOFC.

Berdasar pada desain HTR-PM sebagai referensi, studi ini melakukan perubahan desain pada jumlah resirkulasi bahan bakar pada teras mulai dari nilai awal 15 (desain HTR-PM), 10,5, dan akhirnya resirkulasi tunggal yang dikenal dengan skema OTTO. Dampak dari perubahan skema resirkulasi bahan bakar terhadap performa teras PBR dianalisis berdasarkan hasil perhitungan parameter-parameter desain pada berbagai kondisi tersebut. Optimasi desain PBR dengan skema resirkulasi bahan bakar OTTO diperoleh dengan mengubah daya reaktor sehingga parameter desain memenuhi kriteria desain yaitu nilai maksimum pembangkitan daya per bahan bakar bola yang tidak boleh lebih dari 4,5 kW, dan temperatur bahan bakar pada saat kecelakaan yang tidak boleh lebih dari $1600^{\circ} \mathrm{C}$. Optimasi awal yang dilakukan pada penelitian ini dilakukan dengan mengurangi daya reaktor tanpa mengubah geometri teras serta komposisi bahan bakar desain HTR-PM.

Tabel 1. Parameter Desain HTR-PM sebagai Desain Referensi Kinerja Steam Reformer HTGR [2]

\begin{tabular}{cc}
\hline Parameter, Unit & Nilai \\
\hline Daya Reaktor $[\mathrm{MWt}]$ & 250 \\
Tinggi / diameter teras $[\mathrm{cm}]$ & $1100 / 300$ \\
Temperatur inlet/outlet $\mathrm{He}\left[{ }^{\circ} \mathrm{C}\right]$ & $250 / 750$ \\
Tekanan He primer $[\mathrm{MPa}]$ & 7 \\
Pengayaan U-235 $[\% \mathrm{w} / \mathrm{t}]$ & 8.6 \\
HM-loading per pebble $[\mathrm{g}]$ & 7 \\
Diameter bahan bakar pebble $[\mathrm{cm}]$ & 6 \\
Jumlah bahan bakar pebble dalam & $\sim 420,000$ \\
\hline
\end{tabular}

\section{HASIL DAN PEMBAHASAN}

Data hasil perhitungan rapat daya maksimum teras dengan berbagai skema sirkulasi bahan bakar ditunjukkan pada Gambar 3. Desain teras dengan jumlah sirkulasi bahan bakar 15 adalah desain referensi HTR-PM. Terlihat bahwa dengan mengurangi jumlah sirkulasi bahan bakar pada teras maka rapat daya maksimum akan meningkat. Namun peningkatan yang sangat signifikan terjadi ketika skema OTTO diterapkan dimana terjadi nilai puncak terhadap rerata sekitar tujuh kali lipat. Lebih detail, distribusi aksial rapat daya untuk teras dengan berbagai skema resirkulasi bahan bakar ditunjukkan pada Gambar 4. Selain nilai puncak rapat daya yang semakin meningkat, terlihat bahwa puncak rapat daya juga semakin naik ke bagian atas teras reaktor.

Data hasil perhitungan temperatur bahan bakar dalam keadaan normal ditunjukkan pada Gambar 5. Terlihat bahwa teras dengan skema resirkulasi bahan bakar yang lebih sedikit memiliki temperatur bahan bakar yang lebih tinggi. Untuk skema resirkulasi bahan bakar OTTO, terlihat bahwa nilai rerata temperatur bahan bakar naik lebih signifikan dibandingkan dengan temperatur maksimum bahan bakar bila dibandingkan dengan skema resirkulasi 
bahan bakar lainnya. Peningkatan temperatur maksimum bahan bakar yang tidak terlalu signifikan pada skema resirkulasi OTTO dapat disebabkan oleh posisinya yang memang berada di bagian atas teras dimana pendinginan oleh gas helium masih sangat efektif.

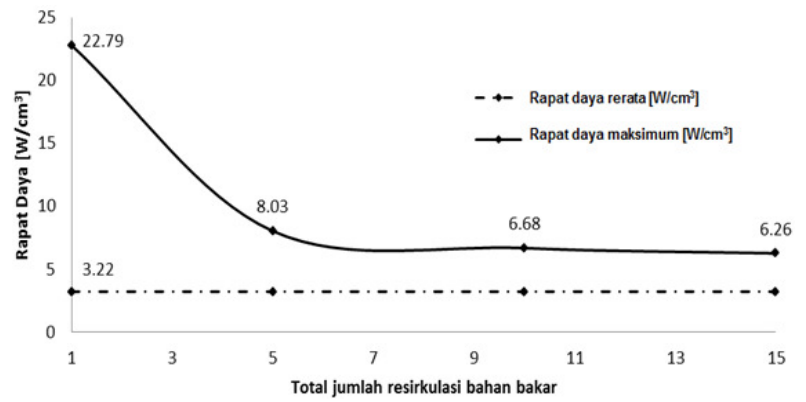

Gambar 3. Rapat Daya Maksimum Untuk Teras Dengan Berbagai Total Jumlah Resirkulasi Bahan Bakar.

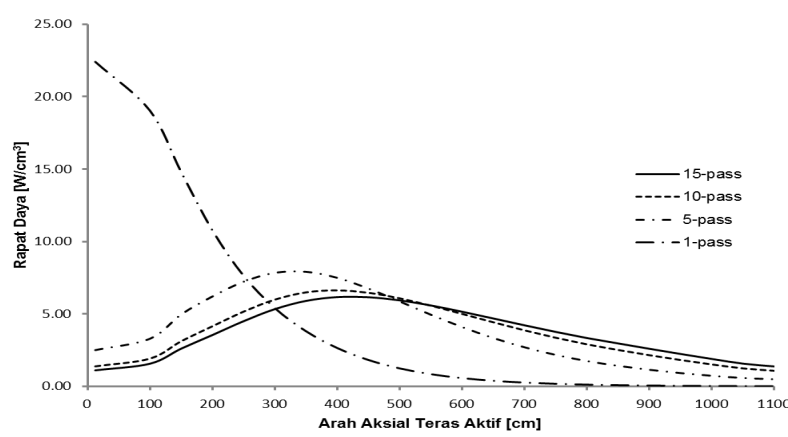

Gambar 4. Distribusi Aksial Rapat Daya Untuk Teras Dengan Berbagai Skema Sirkulasi Bahan Bakar.

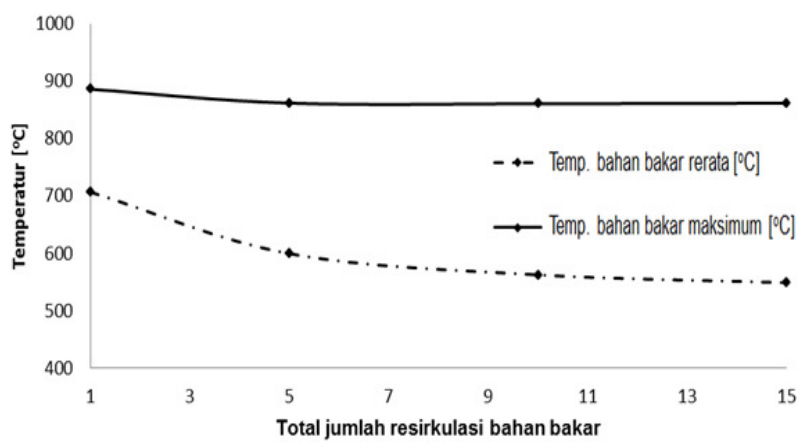

Gambar 5. Temperatur Bahan Bakar Rerata Dan Maksimum Dalam Kondisi Normal.

Data level fraksi bakar teras reaktor untuk berbagai skema resirkulasi bahan bakar ditunjukkan oleh Gambar 6. Data kuantitatif ini menunjukkan bahwa skema dengan resirkulasi bahan bakar lebih sedikit akan menurunkan level fraksi bakar yang diperoleh. Penurunan level fraksi bakar yang signifikan terjadi dengan menerapkan skema resirkulasi OTTO. Namun, ternyata rerata level fraksi bakar bahan bakar yang ada di dalam teras sebaliknya menunjukkan bahwa teras dengan skema resirkulasi yang lebih sedikit memiliki nilai rerata level fraksi bakar yang lebih tinggi. Data ini menunjukkan bahwa pada teras dengan skema resirkulasi lebih banyakakan mengalami rentang variasi level fraksi bakaryang lebih luas. Hal ini terjadi karena memang pada teras dengan resirkulasi bahan bakar lebih banyak heterogenitas level fraksi bakar bahan bakar semakin tinggi.

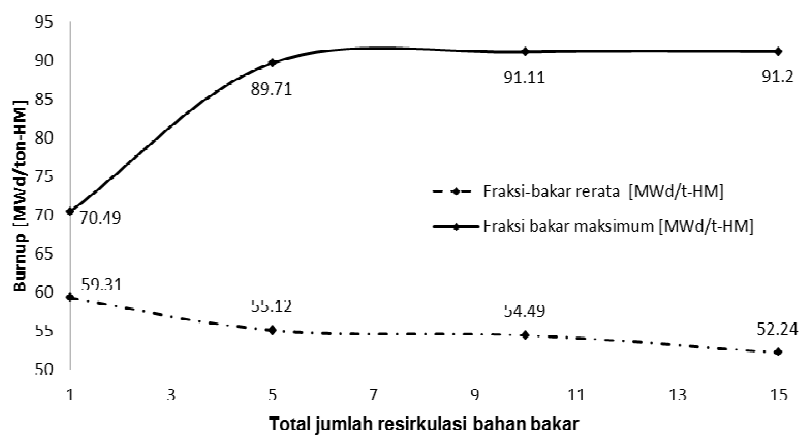

Gambar 6. Fraksi Bakar Rerata Dan Maksimum Untuk Teras Dengan Berbagai Total Jumlah Resirkulasi Bahan Bakar.

Gambar 7 menunjukkan data terkait batas keselamatan yaitu temperatur maksimum setelah terjadi kecelakaan D-LOFC yang dibatasi hingga $1600^{\circ} \mathrm{C}$ dan daya maksimum per pebble yang dibatasi hingga $4,5 \mathrm{~kW} /$ pebble. Terlihat bahwa untuk teras referensi HTRPM, pada pengurangan resirkulasi ke 10 sudah menyebabkan temperatur bahan bakar melebihi batas keselamatan. Pada skema resirkulasi OTTO bahkan dapat dicapai temperatur yang sangat tinggi yaitu $2200^{\circ} \mathrm{C}$.

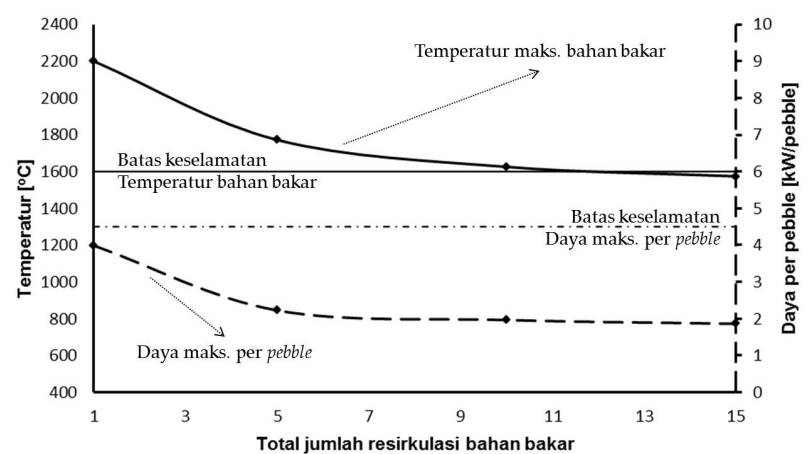

Gambar 7. Temperatur Maksimum Bahan Bakar Setelah Kecelakaan D-LOFC Dan Daya Maksimum Per Bahan Bakar Bola Beserta Masing-Masing Batas Keselamatannya.

Pada Gambar 8-10 diberikan data hasil optimasi awal teras dengan skema resirkulasi OTTO berbasis teras HTR-PM. Untuk dapat 
memenuhi batas keselamatan, pada optimasi awal ini dilakukan penurunan daya teras tanpa mengubah geometri teras maupun komposisi bahan bakar. Gambar 8 menunjukkan distribusi aksial rapat daya untuk berbagai teras dengan skema resirkulasi OTTO dan daya yang diturunkan dari 250 MWt hingga ke 100MWt. Trend distribusi aksial rapat daya dari teras dengan berbagai daya ini masih sama. Trend ini menunjukkan karakteristik skema resirkulasi OTTO dengan puncak rapat daya yang tinggi di bagian atas teras. Hal ini karena hanya bahan bakar segar yang masuk dari atas teras reaktor, sehingga reaksi fisi dan pembangkitan daya mayoritas terjadi pada bagian atas teras. Pada bagian bawah teras, reaksi fisi dan pembangkitan daya semakin kecil karena kandungan bahan fisil bahan bakar semakin berkurang, dikarenakan reaksi fisi dibagian atas teras, juga semakin banyaknya produk fisi yang cenderung menyerap neutron.

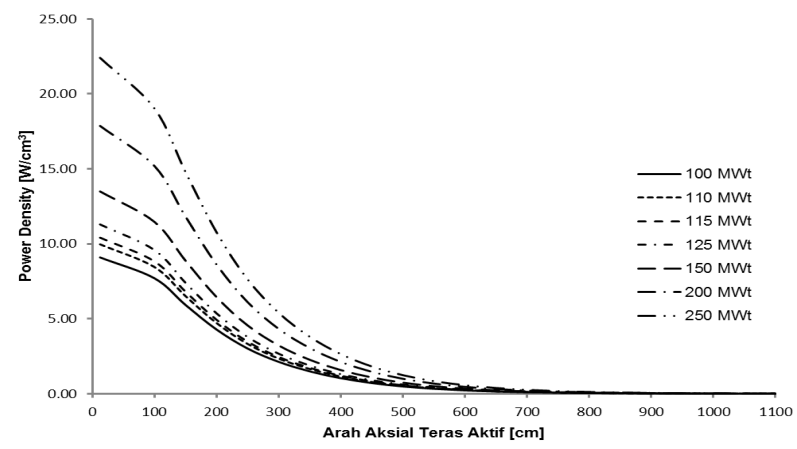

Gambar 8. Distribusi Aksial Rapat Daya Dari Teras Dengan Skema Resirkulasi OTTO Dengan Berbagai Daya.

Data terkait batas keselamatan untuk teras dengan berbagai daya sebagai hasil dari optimasi awal ini ditunjukkan pada Gambar 9. Terlihat bahwa semua teras dapat memenuhi batas keselamatan terkait daya maksimum per pebble, bahkan teras dengan daya maksimum 250 MWt masih memenuhi batas keselamatan ini dengan maksimum daya per pebble sebesar 3,99 kW/pebble. Sedangkan untuk batas keselamatan ketika terjadi kecelakaan DLOFC, terlihat bahwa daya teras perlu diturunkan hingga menjadi $115 \mathrm{MWt}$ dengan temperatur maksimum $1599,4^{\circ} \mathrm{C}$. Detail dari dinamika temperatur bahan bakar setelah terjadinya kecelakaan D-LOFC untuk beberapa teras dengan daya berbeda ditunjukkan pada Gambar 9.

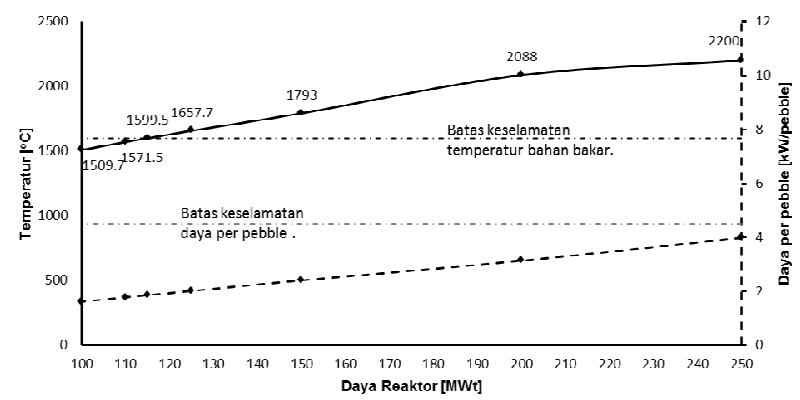

Gambar 9. Temperatur Bahan Bakar Maksimum Ketika Terjadi Kecelakaan D-LOFC Dan Daya Maksimum Per Bahan Bakar Pebble Untuk Teras Dengan Berbagai Daya.

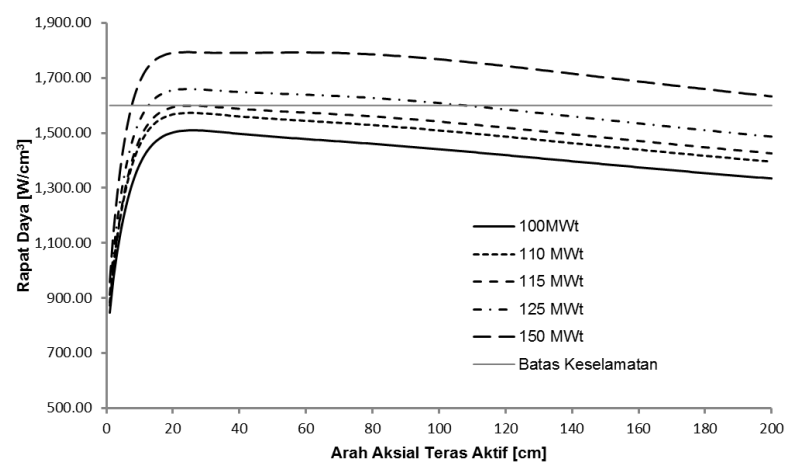

Gambar 10. Dinamika Temperatur Bahan Bakar Setelah Kecelakaan D-LOFC Pada Teras PBR Dengan Berbagai Daya.

Penurunan daya teras untuk memperoleh desain PBR dengan skema OTTO berbasis HTR-PM memang menjadi hal yang merugikan, namun penerapan skema OTTO dapat mengurangi kompleksitas operasional dan biaya pembangunan karena beberapa komponen tidak lagi diperlukan. Optimasi pada penelitian kali ini terbatas pada target tercapainya desain teras PBR dengan operasi lebih sederhana dengan daya optimal 115MWt yang memenuhi batas keselamatan. Desain optimasi awal ini dapat menjadi referensi untuk desain HTR komersial dengan skema pengisian bahan bakar OTTO. Optimasi untuk memperoleh daya yang lebih besar dengan tetap memenuhi batas keselamatan menjadi tantangan dalam penelitian selanjutnya. Perubahan terhadap komposisi bahan bakar dan geometri teras perlu dilakukan dalam penelitian lanjutan untuk mendapatkan optimasi lebih lanjut. 


\section{KESIMPULAN}

Telah dilakukan studi awal desain pebble bed reactor dengan skema sirkulasi bahan bakar OTTO. Hasil studi ini memberikan data kuantitatif mengenai dampak skema resirkulasi bahan bakar yang berbeda terhadap performa teras PBR berbasis teras HTR-PM. Khususnya, dampak dari pemilihan skema OTTO akan memberikan puncak rapat daya yang tinggi dimana nilai puncak per rerata teras referensi dengan 15 sirkulasi adalah sebesar 1,94 akan menjadi sebesar 7,08 dengan menerapkan skema OTTO. Dengan geometri dan komposisi material dan bahan bakar yang sama dengan HTR-PM, penerapan skema OTTO dapat memenuhi batas keselamatan dengan menurunkan daya reaktor hingga ke 115 MWt dengan temperatur maksimum bahan bakar setelah kecelakaan DLOFC sebesar $1599,5^{\circ} \mathrm{C}$. Berkurangnya daya reaktor hingga ke $115 \mathrm{MWt}$ memang menjadi kelemahan dari perubahan desain ini, namun penerapan skema OTTO yang lebih sederhana secara operasional dan berpotensi mengurangi biaya pembangunan tetap menjadi alternatif desain yang menarik.Optimasi lanjutan dengan mengubah geometri dan komposisi bahan bakar menjadi agenda penelitian kedepan.

\section{UCAPAN TERIMA KASIH}

Penulis menyampaikan terimakasih kepada Dr. Hans Gougar dari INL atas izinnya untuk menggunakan perangkat lunak PEBBED. Selain itu juga disampaikan kepada Kepala Pusat Teknologi dan Keselamatan Reaktor Nuklir (PTKRN) BATAN, Dr. Geni Rina Sunaryo, atas dukungannya (melalui DIPA 080.01.1.450310/2015) sehingga kerjasama dengan INL bisa terjalin yang memungkinkan dilakukannya penelitian ini.

\section{DAFTAR ACUAN}

[1] A.C. Kadak. "The Status of the US HighTemperatur Gas Reactors". Engineering, Volume 2, 2016, 119-123.

[2] Z. Zhang, Y. Dong, F. Li, Z. Zhang, H. Wang, X. Huang, H. Li, B. Liu, X. Wu, H. Wang, X Diao, H. Zhang, J. Wang. " The Shandong Shidao Bay 200 MWe High-Temperatur Gas-Cooled Reactor Pebble-Bed Module (HTR-PM) Demonstration Power Plant: An Engineering and Technological Innovation”. Engineering, Volume 2, 2016, 112 118.

[3] T. Setiadipura, D. Irwanto, Zuhair. "Preliminary Neutronic Design of High Fraksi bakar OTTO Cycle Pebble Bed Reactor“. Atom Indonesia, Volume 41 No. 1, 2015, 7-15.

[4] U.Hansen, R.Schulten, E.Teuchert. "Physical properties of the Once Through Then Out pebblebed reactor". Nuclear Science and Engineering, Volume 47, 1972, 132-139.

[5] T. Setiadipura, T. Obara. "Optimization of Start-up Fuel Management for OTTO Cycle Pebble Bed Reactor". Energy Procedia, Volume 71, 2015, 4251.

[6] H. N. Tran. "Fuel Fraksi bakar Performance of an OTTO refueling pebble bed reactor with burnable poison loading”. Progress in Nuclear Engineering, Volume 60, 2012, 47-52.

[7] F. LI, X. Jing, 2004. "Comparison of Fuel Loading Pattern in HTR-PM". 2nd International Topical Meeting on High Temperatur Reactor Technology, Beijing, China.

[8] P. Huang, X. Liang, X. Chen. "The operation characteristic of the fuel handling system of HTR10". in Proceedings of the 18th Intenational Conference on Nuclear Engineering ICONE18, China, 2010.

[9] H.D. Gougar, A.M. Ougouag, W.K. Terry. "Automated Design and Optimization of Pebble-Bed Reactor Cores”. Nuclear Science and Engineering Volume 165, 2010, 245-269.

[10] B.Boer, A.M. Ougouag. 2011. "Final Report on Utilization of TRU TRISO Fuel as Applied to HTR System, Part 1: Pebble Bed Reactors", AS: Idaho National Laboratory.

[11] H.D. Gougar, F. Reitsma, w. Joubert, 2009. "A Comparison of Pebble Mixing and Depletion Algorithms Used in Pebble-Bed Reactor Equilibrium Cycle Simulation". International Conference on Mathematics, Computational Methods \& Reactor Physics (M\&C 2009), AS.

[12] W.Y. Yoon, R.A. Grimesey, D.W. Nigg, R.L. Curtis. 2008. "COMBINE7.0 - A Portable ENDF/B-VII.0 Based Neutron Spectrum and Cross-Section Generation Program". AS: Idaho National Laboratory. 